\title{
Ruthenium and osmium carbonyl clusters incorporating stannylene and stannyl ligands
}

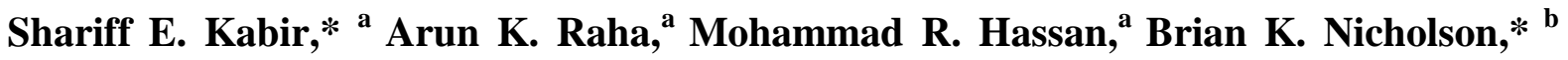 \\ Edward Rosenberg, * ${ }^{c}$ Ayesha Sharmin, ${ }^{c}$ Luca Salassa ${ }^{c}$ \\ ${ }^{a}$ Department of Chemistry, Jahangirnagar University, Savar, Dhaka 1342, Bangladesh \\ ${ }^{b}$ Department of Chemistry, University of Waikato, Hamilton, New Zealand \\ ${ }^{c}$ Department of Chemistry, The University of Montana, Missoula, Montana 59812, USA
}

\section{Summary}

The reaction of $\left[\mathrm{Ru}_{3}(\mathrm{CO})_{12}\right]$ with $\mathrm{Ph}_{3} \mathrm{SnSPh}$ in refluxing benzene furnished the bimetallic Ru-Sn compound $\left[\mathrm{Ru}_{3}(\mathrm{CO})_{8}(\mu-\mathrm{SPh})_{2}\left(\mu_{3}-\mathrm{SnPh}_{2}\right)\left(\mathrm{SnPh}_{3}\right)_{2}\right] \mathbf{1}$ which consists of a $\mathrm{SnPh}_{2}$ stannylene bonded to three $\mathrm{Ru}$ atoms to give a planar tetra-metal core, with two peripheral $\mathrm{SnPh}_{3}$ ligands. The stannylene ligand forms a very short bond to one $\mathrm{Ru}$ atom $[\mathrm{Sn}-\mathrm{Ru}$ 2.538(1) $\AA$ ] and very long bonds to the other two [Sn-Ru 3.074(1) $\AA$ ]. The germanium compound $\left[\mathrm{Ru}_{3}(\mathrm{CO})_{8}(\mu-\mathrm{SPh})_{2}\left(\mu_{3}-\mathrm{GePh}_{2}\right)\left(\mathrm{GePh}_{3}\right)_{2}\right] 2$ was obtained from the reaction of $\left[\mathrm{Ru}_{3}(\mathrm{CO})_{12}\right]$ with $\mathrm{Ph}_{3} \mathrm{GeSPh}$ and has a similar structure to that of $\mathbf{1}$ as evidenced by spectroscopic data. Treatment of $\left[\mathrm{Os}_{3}(\mathrm{CO})_{10}(\mathrm{MeCN})_{2}\right]$ with $\mathrm{Ph}_{3} \mathrm{SnSPh}$ in refluxing benzene yielded the bimetallic Os-Sn compound $\left[\mathrm{Os}_{3}(\mathrm{CO})_{9}(\mu-\mathrm{SPh})\left(\mu_{3}-\mathrm{SnPh}_{2}\right)(\mathrm{MeCN})\left(\eta^{1}-\mathrm{C}_{6} \mathrm{H}_{5}\right)\right] 3$. Cluster 3 has a superficially similar planar metal core, but with a different bonding mode with respect to that of 1 . The $\mathrm{Ph}_{2} \mathrm{Sn}$ group is bonded most closely to Os(2) and $\mathrm{Os}(3)$ [2.7862(3) and 2.7476(3) Å respectively] with a significantly longer bond to Os(1), 2.9981(3) $\AA$ indicating a weak back-donation to the Sn. The reaction of the bridging dppm compound $\left[\mathrm{Ru}_{3}(\mathrm{CO})_{10}(\mu\right.$-dppm) $]$ with $\mathrm{Ph}_{3} \mathrm{SnSPh}$ afforded $\left[\mathrm{Ru}_{3}(\mathrm{CO})_{6}(\mu\right.$-dppm $\left.)\left(\mu_{3}-\mathrm{S}\right)\left(\mu_{3}-\mathrm{SPh}\right)\left(\mathrm{SnPh}_{3}\right)\right] \mathbf{5}$. Compound 5 contains an open triangle of $\mathrm{Ru}$ atoms simultaneously capped by a sulfido and a $\mathrm{PhS}$ ligand on opposite sides of the cluster with a dppm ligand bridging one of the $\mathrm{Ru}-\mathrm{Ru}$ edges and a $\mathrm{Ph}_{3} \mathrm{Sn}$ group occupying an axial position on the $\mathrm{Ru}$ atom not bridged by the dppm ligand. 


\section{Introduction}

Recently, bimetallic cluster complexes have attracted great interest because of their use as precursors to bimetallic nanoparticles by gentle thermolysis on high surface area mesoporous supports and have been shown to be superior catalysts for hydrogenation reactions. ${ }^{1}$ Tin $^{2-5}$ and germanium ${ }^{6}$ are widely used to modify and enhance the activity of bimetallic catalysts leading to increased selectivity in a variety of chemical transformations. ${ }^{2}$ There is also evidence that tin can assist in the binding of metallic nanoparticles to oxide supports when used in heterogeneous catalysis. ${ }^{3-5,7}$ Oxidative addition of $\mathrm{R}_{3} \mathrm{M}^{\prime} \mathrm{H}\left(\mathrm{M}^{\prime}=\mathrm{Si}\right.$, Sn or $\mathrm{Ge} ; \mathrm{R}=\mathrm{Et}, \mathrm{Bu}$ or $\mathrm{Ph})$ to the lightly stabilized $\left[\mathrm{M}_{3}(\mathrm{CO})_{12-\mathrm{n}}(\mathrm{NCMe})_{\mathrm{n}}\right](\mathrm{n}=1$ or 2$)$ gives mixed metal clusters of the type $\left[\mathrm{M}_{3}(\mathrm{CO})_{11}\left(\mathrm{M}^{\prime} \mathrm{R}_{3}\right)(\mu-\mathrm{H})\right]$ and $\left[\mathrm{M}_{3}(\mathrm{CO})_{10}\left(\mathrm{CH}_{3} \mathrm{CN}\right)\left(\mathrm{M}^{\prime} \mathrm{R}_{3}\right)(\mu-\right.$ $\mathrm{H})]\left(\mathrm{M}=\mathrm{Ru}, \mathrm{Os} ; \mathrm{M}^{\prime}=\mathrm{Ge}, \mathrm{Sn} ; \mathrm{R}=\mathrm{Me}, \mathrm{Et}, \mathrm{Bu}\right.$ or $\left.\mathrm{Ph}\right) .{ }^{8}$ It has also been reported that the unsaturated $\left[\mathrm{Os}_{3}(\mathrm{CO})_{10}(\mu-\mathrm{H})_{2}\right]$ reacts analogously with $\mathrm{R}_{3} \mathrm{M}^{\prime} \mathrm{H}$ giving $\left[\mathrm{Os}_{3}(\mathrm{CO})_{10}\left(\mathrm{M}_{3} \mathrm{R}_{3}\right)(\mu-\right.$ $\left.\mathrm{H})_{3}\right]^{9}$. Adams et al. recently reported that reactions of $\mathrm{Ph}_{3} \mathrm{SnH}$ with metal carbonyl cluster complexes leads to the formation of polynuclear metal carbonyl complexes containing $\mu$ $\mathrm{SnPh}_{2}, \mu_{3}-\mathrm{SnPh}$, or $\mu_{4}-\mathrm{Sn}$ ligands by the cleavage of phenyl groups. ${ }^{10}$ For example, the highnuclearity bimetallic Ru-Sn cluster compounds, $\left[\mathrm{Ru}_{5}(\mathrm{CO})_{10}\left(\mathrm{SnPh}_{3}\right)\left(\mu-\mathrm{SnPh}_{2}\right)_{4}\left(\mu_{5}-\mathrm{C}\right)(\mu-\mathrm{H})\right]$ and $\left[\mathrm{Ru}_{5}(\mathrm{CO})_{7}\left(\mathrm{SnPh}_{3}\right)\left(\mu-\mathrm{SnPh}_{2}\right)_{4}\left(\mu_{5}-\mathrm{C}\right)(\mu-\mathrm{H})\right]$, containing five tin ligands are formed from the reactions of $\left[\mathrm{Ru}_{5}(\mathrm{CO})_{15}\left(\mu_{5}-\mathrm{C}\right)\right]$ or $\left[\mathrm{Ru}_{5}(\mathrm{CO})_{12}\left(\mathrm{C}_{6} \mathrm{H}_{6}\right)\left(\mu_{5}-\mathrm{C}\right)\right]$ with $\mathrm{Ph}_{3} \mathrm{SnH}^{10 a}$ Very recently the bimetallic complexes $\left[\mathrm{Os}_{3}(\mathrm{CO})_{11}\left(\mathrm{SnPh}_{3}\right)(\mu-\mathrm{H})\right]$ and $\left[\mathrm{Os}_{3}(\mathrm{CO})_{9}\left(\mu-\mathrm{SnPh}_{2}\right)_{3}\right]$ were reported from the reaction of $\left[\mathrm{Os}_{3}(\mathrm{CO})_{12}\right]$ with $\mathrm{Ph}_{3} \mathrm{SnH}$. These complexes undergo reaction across the Os-Sn bond with $\mathrm{Pt}\left(\mathrm{PBu}_{3}^{\mathrm{t}}\right)_{2}$ to yield $\left[\mathrm{Os}_{3}(\mathrm{CO})_{9}\left\{\mathrm{Pt}\left(\mathrm{PBu}_{3}^{\mathrm{t}}\right)\right\}\left(\mu-\mathrm{SnPh}_{2}\right)_{3}\right]$ and $\left[\mathrm{Os}_{3}(\mathrm{CO})_{9}\left\{\mathrm{Pt}(\mathrm{Ph})\left(\mathrm{PPh}_{3}\right)_{2}\right\}\left(\mu-\mathrm{SnPh}_{2}\right)_{2}\left(\mu_{3}-\mathrm{SnPh}\right)\right]$ by insertion of a $\mathrm{Pt}\left(\mathrm{PPh}_{3}\right)_{2}$ group into one of the $\mathrm{Sn}-\mathrm{Ph}$ bonds. ${ }^{10 \mathrm{~d}, \mathrm{f}}$ Thermolysis of $\left[\mathrm{Os}_{3}(\mathrm{CO})_{11}\left(\mathrm{SnPh}_{3}\right)(\mu-\mathrm{H})\right]$ under a $\mathrm{CO}$ atmosphere gives $\left[\mathrm{Os}_{3}(\mathrm{CO})_{12}(\mathrm{Ph})\left(\mu_{3}-\mathrm{SnPh}_{3}\right)\right]$ and $\left[\mathrm{Os}_{4}(\mathrm{CO})_{16}\left(\mu_{4}-\mathrm{Sn}\right)\right] .{ }^{10 \mathrm{e}}$ In recent studies we have found that both the electronically unsaturated $\left[\mathrm{Os}_{3}(\mathrm{CO})_{8}\left(\mathrm{Ph}_{2} \mathrm{PCH}_{2} \mathrm{P}(\mathrm{Ph}) \mathrm{C}_{6} \mathrm{H}_{4}\right)(\mu-\mathrm{H})\right]$ and electron precise $\left[\mathrm{Os}_{3}(\mathrm{CO})_{10}(\mu\right.$-dppm) $]$ react with $\mathrm{Ph}_{3} \mathrm{SnH}$ to yield a series of novel Os-Sn complexes. ${ }^{11}$ As far as we are aware, no examples of transition metal bimetallic clusters containing sulfur-metal and tin-metal bonds in the same molecule have been reported. It 
occurred to us that the presence of a potentially capping sulfur ligand could induce the stannyl moieties to adopt new bonding modes in the resulting bimetallic clusters. We have now investigated the reactions of tetraphenylthiostannane with $\left[\mathrm{Ru}_{3}(\mathrm{CO})_{12}\right]$, $\left[\mathrm{Os}_{3}(\mathrm{CO})_{10}(\mathrm{MeCN})_{2}\right]$ and $\left[\mathrm{Ru}_{3}(\mathrm{CO})_{10}(\mu-\mathrm{dppm})\right]$. The objectives were to synthesize bimetallic complexes with sulfur and tin ligands in unusual bonding modes which could be used as precursors to nanoconductors, because the presence of two functionalities in one molecule proffers an extended $\pi$-electron system with possible metal-metal interactions. Besides the structural characterization the electronic structures of these compounds were investigated by DFT calculations and also the electrochemical properties of the products were studied in an attempt to gain a further understanding of how changes in the bonding mode of the ligands to a trimetallic core impacts its electron acceptor-donor properties.

\section{Results and discussion}

The reaction of $\left[\mathrm{Ru}_{3}(\mathrm{CO})_{12}\right]$ with $\mathrm{Ph}_{3} \mathrm{SnSPh}$ in refluxing benzene resulted in the isolation of the bimetallic cluster $\left[\mathrm{Ru}_{3}(\mathrm{CO})_{8}(\mu-\mathrm{SPh})_{2}\left(\mu_{3}-\mathrm{SnPh}_{2}\right)\left(\mathrm{SnPh}_{3}\right)_{2}\right] \mathbf{1}$ in $18 \%$ yield (Scheme 1). Characterization of $\mathbf{1}$ was by X-ray crystallography and spectroscopic data.

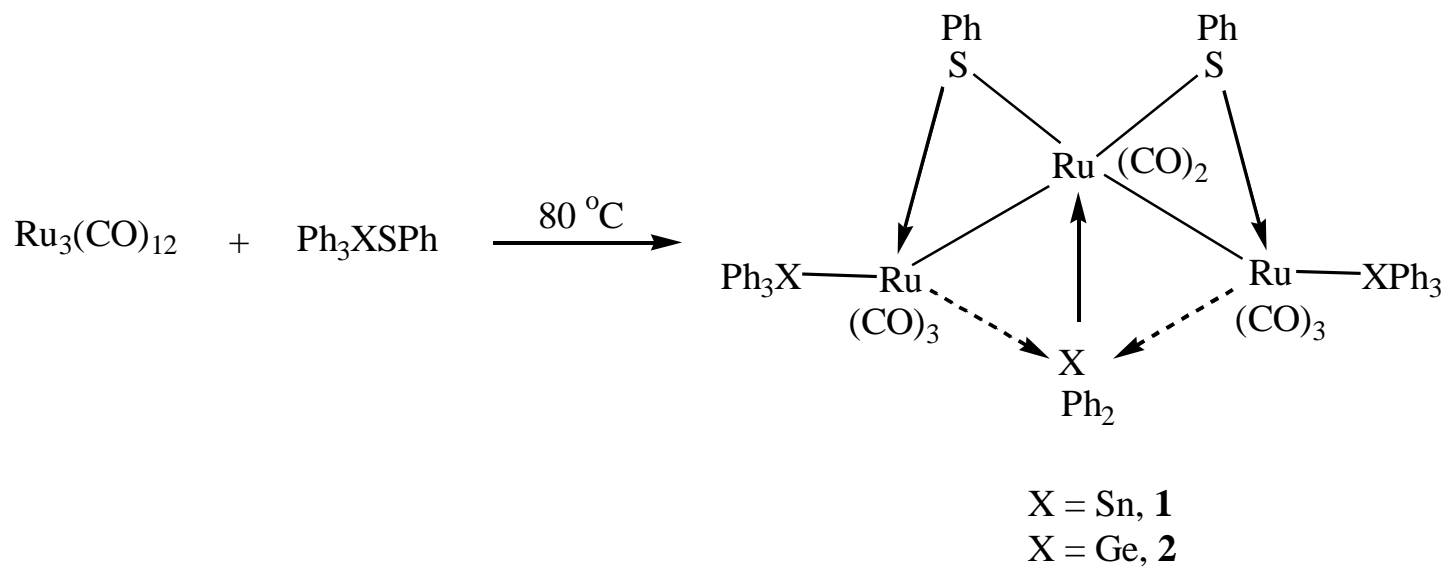

\section{Scheme 1}

The structure of the cluster is illustrated in Figure 1, with selected parameters given in the caption. The molecule consists of three $\mathrm{Ru}$ atoms, each bonded to the $\mathrm{SnPh}_{2}$ group to give a planar tetra-metal core. Each of the Ru-Ru edges is bridged by a $\mu-\mathrm{SPh}$ group, positioned to give shorter distances to the outer $\mathrm{Ru}$ atoms. There is a terminal $\mathrm{Ph}_{3} \mathrm{Sn}$ group attached to the 
outer $\mathrm{Ru}$ atoms, with remaining coordination sites occupied by $\mathrm{CO}$ ligands. The terminal $\mathrm{Ph}_{3} \mathrm{Sn}$ groups have a normal Sn-Ru bond length of 2.682(1) $\AA$. The most unusual feature is the bonding of the $\mathrm{Ph}_{2} \mathrm{Sn}$ group. This forms a very short 2.538(1) $\AA$ link to $\mathrm{Ru}(2)$, and extremely long bonds to $\mathrm{Ru}(1)$ and $\mathrm{Ru}(3)$ (av. 3.074(1) $\AA$ ). A search of the Cambridge Crystallographic Database ${ }^{12}$ for $\mathrm{Sn}-\mathrm{Ru}$ bonds where there is also at least one $\mathrm{Sn}-\mathrm{C}$ bond shows a range of 2.60-2.76 ̊. Therefore the $\mathrm{Ru}(2)-\mathrm{Sn}(3)$ bond in 1 represents an unusually short $\mathrm{Ru}-\mathrm{Sn}$ bond while the $\mathrm{Ru}(1)-\mathrm{Sn}(3)$ and $\mathrm{Ru}(3)-\mathrm{Sn}(3)$ bonds are borderline non-bonding. This suggests that the $\mathrm{Ph}_{2} \mathrm{Sn}$ group can be considered as a singlet stannylene, forming a strong $\sigma$-donor bond via its $\mathrm{sp}^{2}$ lone pair of electrons to $\mathrm{Ru}(2)$, and is stabilized by weak back-donation to the $\mathrm{Sn}$ from $\mathrm{Ru}(1)$ and $\mathrm{Ru}(3)$. This can be represented formally as shown in Scheme 1.

This representation also accommodates the unsymmetrical bonding of the $\mathrm{SPh}$ groups, and gives a formal eighteen-electron count for each of the $\mathrm{Ru}$ atoms. $\mathrm{R}_{2} \mathrm{Sn}$ ligands bonded as a stannylene in mononuclear complexes have been long-known when $\mathrm{R}$ is a very bulky group, as in $\left[\left\{\left(\mathrm{Me}_{3} \mathrm{Si}\right)_{2} \mathrm{HC}\right\}_{2} \mathrm{SnCr}(\mathrm{CO})_{5}\right]$ and other related examples ${ }^{13}$, but this type of bonding for $\mathrm{R}_{2} \mathrm{Sn}$ in polymetallic compounds is unusual, because in transition metal clusters these normally bridge a metal-metal bond as part of a closed triangle ${ }^{10 \mathrm{~d}, 14}$. The closest analogues are from Adam's group ${ }^{10 \mathrm{~d}, 15}$, where some Re-Pt and Os-Pt clusters incorporate a fivecoordinate $\mathrm{Ph}_{2} \mathrm{Sn}$ ligand related to that in $\mathbf{1}$, but where the bond distances to the three metal atoms are much more uniform.

The spectroscopic data of $\mathbf{1}$ are fully consistent with the solid-state structure. Despite the very different chemical environments for the $\mathrm{Ph}_{3} \mathrm{Sn}$ and $\mathrm{Ph}_{2} \mathrm{Sn}$ groups, the ${ }^{119} \mathrm{Sn}$ NMR spectrum of 1 showed only a small difference in chemical shift, with signals at $\delta-25.3$ and -29.9 respectively relative to $\mathrm{SnMe}_{4}$. The FAB mass spectrum showed the molecular ion peak at $\mathrm{m} / \mathrm{z}$ 1719. The electrospray mass spectrum of $\mathbf{1}$ in $\mathrm{MeOH}$ (with added $\mathrm{NaOMe}$ to aid ionisation $^{16}$ ) gave not only a weak peak corresponding to the expected [M+OMe]', but also one assignable to $[\mathrm{M}]^{-}$through reduction in the mass spectrometer source, a relatively rare ionization process. The main signal was at $\mathrm{m} / z, 1369$ which corresponds to [M-SnPh$]^{-}$, arising from remarkably facile loss of the $\mathrm{Ph}_{3} \mathrm{Sn}^{+}$group in the mass spectrometer.

Although there have been major efforts to prepare $\mathrm{Ru}-\mathrm{Sn}$ and Os-Sn bimetallic cluster complexes in recent years, to date few examples of ruthenium carbonyl cluster complexes 
containing germanium ligands have been reported. ${ }^{17}$ Adams et al. ${ }^{18}$ have very recently shown that $\left[\mathrm{M}_{4}(\mathrm{CO})_{12}(\mu-\mathrm{H})_{4}\right](\mathrm{M}=\mathrm{Os}, \mathrm{Ru})$ react with $\mathrm{Ph}_{3} \mathrm{GeH}$ leading to the formation of $\left[\mathrm{M}_{4}(\mathrm{CO})_{10-\mathrm{n}}\left(\mu_{4}-\mathrm{GePh}\right)_{2}\left(\mu-\mathrm{GePh}_{2}\right)_{2+\mathrm{n}}\right]$ (where $\mathrm{M}=\mathrm{Ru}, \mathrm{n}=0,1,2$, and where $\mathrm{M}=\mathrm{Os}, \mathrm{n}=1$, 2) containing an unusually large number of phenylgermanium ligands. To see whether $\mathrm{Ph}_{3} \mathrm{GeSPh}$ can engage in a similar reaction to that of $\mathrm{Ph}_{3} \mathrm{SnSPh}$ we have investigated its reaction with $\left[\mathrm{Ru}_{3}(\mathrm{CO})_{12}\right]$. Treatment of $\left[\mathrm{Ru}_{3}(\mathrm{CO})_{12}\right]$ with $\mathrm{Ph}_{3} \mathrm{GeSPh}$ in refluxing benzene resulted in the isolation of $\left[\mathrm{Ru}_{3}(\mathrm{CO})_{8}(\mu-\mathrm{SPh})_{2}\left(\mu_{3}-\mathrm{GePh}_{2}\right)\left(\mathrm{GePh}_{3}\right)_{2}\right] 2$ in $15 \%$ yield $(\mathrm{Scheme}$ 1). Formation of compound $\mathbf{2}$ is proposed on the basis of elemental analysis, mass spectral data and the similarity of the IR and NMR data to 1. The infrared spectrum of 2, in the carbonyl region is very similar to that of $\mathbf{1}$ and the proton NMR shows a similar pattern in the aromatic region to $\mathbf{1}$ indicating that they are isostructural. The FAB mass spectrum of $\mathbf{2}$ exhibits a molecular ion peak at m/z 1581 consistent with its formulation.

The reaction of $\left[\mathrm{Os}_{3}(\mathrm{CO})_{10}(\mathrm{NCMe})_{2}\right]$ with $\mathrm{Ph}_{3} \mathrm{SnSPh}$ in refluxing benzene resulted in the isolation of $\left[\mathrm{Os}_{3}(\mathrm{CO})_{9}(\mu-\mathrm{SPh})\left(\mu-\mathrm{SnPh}_{2}\right)(\mathrm{NCMe})\left(\eta^{1}-\mathrm{C}_{6} \mathrm{H}_{5}\right)\right] 3$ in $27 \%$ yield (Scheme 2). Compound $\mathbf{3}$ has been characterized by a combination of spectroscopic data and single crystal X-ray diffraction studies.

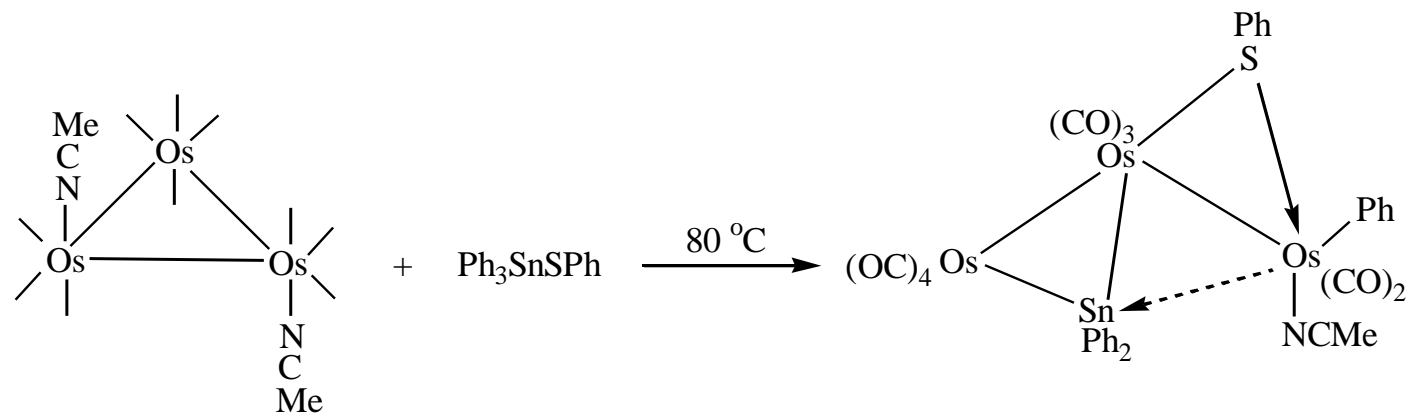

3

\section{Scheme 2}

The $\mathrm{Os}_{3} \mathrm{Sn}$ cluster $\mathbf{3}$ has a superficially similar metal core to that of $\mathbf{1}$, but the details are different. As shown in Figure 2, again there is a planar array for the metal atoms, but the $\mathrm{Ph}_{2} \mathrm{Sn}$ group is bonded most closely to Os(2) and Os(3) [2.7862(3) and 2.7476(3) $\AA$ respectively] with a significantly longer bond to Os(1), 2.9981(3) A. One of the Os-Os bonds is also bridged by the $\mathrm{PhS}$ ligand and is longer $[\mathrm{Os}(1)-\mathrm{Os}(2)=3.039 \AA$ ] than the unbridged 
Os(2)-Os(3) at $2.999 \AA$. Both of these are at the longer end of the range of Os-Os bonds reported in the literature. Os(1) is also attached to a terminal phenyl group, and to a $\mathrm{MeCN}$ ligand. Overall the bonding in cluster $\mathbf{3}$ is formally represented as drawn in Scheme 2. The closest analog for this cluster is $\left[\mathrm{Os}_{3}\left(\mu_{3}-\mathrm{SnCl}_{2}\right)\left(\mu-\mathrm{CH}_{2}\right)(\mathrm{CO})_{11}\right]$, reported by Geoffroy's group ${ }^{19}$. This has a $\mathrm{SnCl}_{2}$ in place of the $\mathrm{Ph}_{2} \mathrm{Sn}$ in $\mathbf{2}$, and a bridging methylene instead of a $\mu$ $\mathrm{SPh}$, but is otherwise similar. For this earlier example the different Os-Sn bond lengths form a similar pattern to that found for $\mathbf{2}$, though all are shorter as expected with more electronegative $\mathrm{Cl}$ substituents on the tin atom. The Os-Os bonds are very similar in both examples. The spectroscopic data for $\mathbf{3}$ are fully consistent with the solid-state structure. The FAB mass spectrum shows the molecular ion peak at $\mathrm{m} / \mathrm{z} 1323$. The electrospray mass spectrum of 3 in $\mathrm{MeOH}$ shows clean signals assignable to both $[\mathrm{M}+\mathrm{OMe}]^{-}$at $\mathrm{m} / \mathrm{z} 1354$ and $[\mathrm{M}+\mathrm{OMe}-\mathrm{MeCN}]^{-}$at $\mathrm{m} / \mathrm{z} 1313$ under mild conditions (cone voltage $<20 \mathrm{~V}$ ), indicating a labile NCMe group. Loss of CO ligands only took place at cone voltages $>50 \mathrm{~V}$. In addition to the phenyl proton resonances, the ${ }^{1} \mathrm{H}$ NMR spectrum contains a singlet at $\delta 1.69$ assigned to the methyl protons of the coordinated NCMe ligand.

Treatment of $\left[\mathrm{Ru}_{3}(\mathrm{CO})_{10}(\mu\right.$-dppm) $]$ (4) with $\mathrm{Ph}_{3} \mathrm{SnSPh}$ in refluxing benzene afforded $\left[\mathrm{Ru}_{3}(\mathrm{CO})_{6}\left(\mu\right.\right.$-dppm) $\left.\left(\mu_{3}-\mathrm{S}\right)\left(\mu_{3}-\mathrm{SPh}\right)\left(\mathrm{SnPh}_{3}\right)\right] 5$ in $54 \%$ yield (Scheme 3$)$, which has been characterized by a combination of spectroscopic data and single crystal X-ray diffraction studies.

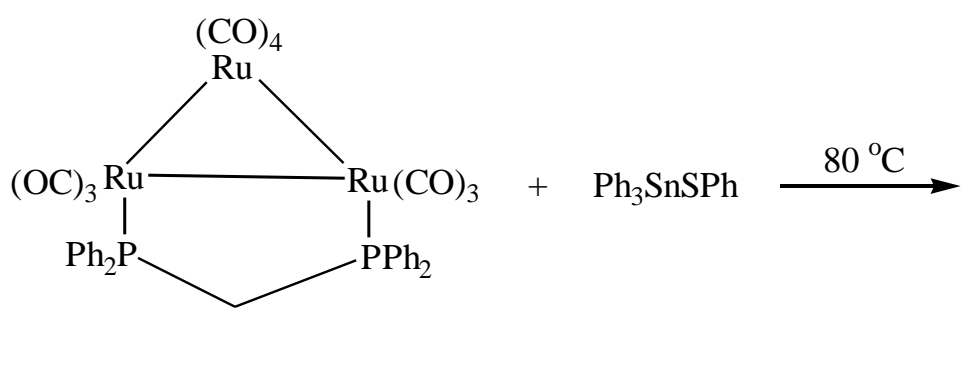

4

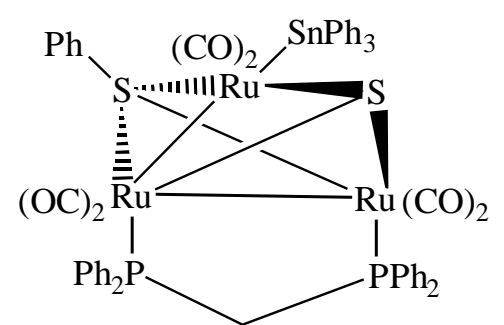

5

\section{Scheme 3}

The structure of $\mathbf{5}$ is given in Figure 3, which shows a completely different species to that obtained from the same reaction with $\left[\mathrm{Ru}_{3}(\mathrm{CO})_{12}\right]$. In this case the $\mathrm{Ph}_{3} \mathrm{Sn}$ group remains 
intact and is coordinated to one $\mathrm{Ru}$ atom. The three $\mathrm{Ru}$ atoms form an open triangle bridged on one side by a $\mathrm{PhS}^{-}$ligand, and on the other by an $\mathrm{S}^{2-}$ one. An alternative view, emphasised in Figure 3, is as a $\mathrm{Ru}_{3} \mathrm{~S}_{2}$ square-pyramidal cluster core, with a dppm bridging one $\mathrm{Ru}-\mathrm{Ru}$ edge, a $\mathrm{Ph}_{3} \mathrm{Sn}$ group occupying an axial position on the other $\mathrm{Ru}$ atom, and with a $\mathrm{Ph}$ group in an equatorial site on one of the $\mathrm{S}$ atoms. The six CO ligands, each rurhenium atom containing two, complete the coordination. An interesting feature is the sulfido and the $\mathrm{SPh}$ ligands, formed by cleavage of C-S and Sn-S bonds of the ligand, respectively, which asymmetrically cap the $\mathrm{Ru}_{3}$ system $[\mathrm{S}(2)-\mathrm{Ru}(1)=2.4476(6), \mathrm{S}(2)-\mathrm{Ru}(2)=2.4432(6), \mathrm{S}(2)$ $\mathrm{Ru}(3)=2.4746(6) \AA$ and $\mathrm{S}(1)-\mathrm{Ru}(1)=2.3562(6), \mathrm{S}(1)-\mathrm{Ru}(2)=2.4130(6), \mathrm{S}(1)-\mathrm{Ru}(3)=$ 2.3371(6) $\AA$ ]. Of the two Ru-Ru bonds, the $R u(2)-R u(3)$ distance of 2.7481(3) $\AA$ supported by the bridging dppm ligand is significantly shorter than the unsupported $\operatorname{Ru}(1)-\operatorname{Ru}(2)$ distance of 2.9030(3) $\AA$. The former is also significantly shorter than the corresponding dppm bridged $\mathrm{Ru}-\mathrm{Ru}$ distance in $\left[\mathrm{Ru}_{3}(\mathrm{CO})_{10}(\mu\right.$-dppm) $]\left[(2.834(1) \AA]^{20}\right.$

The spectroscopic data of $\mathbf{5}$ in solution are consistent with the solid-state structure. In addition to the phenyl proton resonances of the triphenyltin, capping $\mathrm{PhS}$ and bridging dppm ligands, the ${ }^{1} \mathrm{H}$ NMR spectrum in the aliphatic region exhibits two multiplets at $\delta 4.18$ and 3.70 due to the diastereotopic methylene protons of the dppm ligand. The ${ }^{31} \mathrm{P}\left\{{ }^{1} \mathrm{H}\right\}$ NMR spectrum of exhibits two doublets at $\delta 32.6(J=88.1 \mathrm{~Hz})$ and $-13.2(J=88.1 \mathrm{~Hz})$, implying inequivalent ${ }^{31} \mathrm{P}$ nuclei of the dppm ligand. The ${ }^{119} \mathrm{Sn}$ NMR spectrum of 5 shows a similar shift for the $\mathrm{Ph}_{3} \mathrm{Sn}$ group as in the case of $\mathbf{1}$, with a signal at $\delta-28.6$ showing a $15 \mathrm{~Hz}$ coupling to one $\mathrm{P}$ atom of the dppm ligand, which is consistent with the structure found by X-ray crystallography. The FAB mass spectrum shows the molecular ion peak at m/z 1348 . The electrospray mass spectra gave a clean $[\mathrm{M}+\mathrm{Na}]^{+}$signal centred at $\mathrm{m} / \mathrm{z} 1371$ in positive ion mode, and an $[\mathrm{M}-\mathrm{H}]^{-}$peak at $\mathrm{m} / \mathrm{z} 1347$ arising from abstraction of a methylene $\mathrm{H}$ from the dppm ligand, a common ionisation process for dppm-substituted clusters. ${ }^{16,21}$ Both of these ions were remarkably robust, undergoing $\mathrm{CO}$ loss only at high cone voltages, $>60 \mathrm{~V}$, and in contrast to the very ready loss of $\mathrm{Ph}_{3} \mathrm{Sn}^{+}$from 1, there was no indication at all of a similar process for 5 .

The cyclic voltamograms for clusters $\mathbf{1}$ and $\mathbf{5}$ in dichloromethane show irreversible reduction waves at -1.22 and $-1.37 \mathrm{~V}$ and irreversible oxidation waves at +1.12 and $+0.87 \mathrm{~V}$ respectively relative to the ferrocene/ferrocenium ion couple. That cluster $\mathbf{5}$ shows a more 
negative reduction and more positive oxidation half wave potential can be attributed to the presence of the electron donating properties of the dppm but the significant difference in their structure make even this conclusion tentative.

Calculation of the optimized geometries of complexes $\mathbf{1}$ and $\mathbf{3}$ was performed in order to gain some further insight into the nature of the bonding between the $\mathrm{Sn}$ and the $\mathrm{Ru}$ or Os atoms in the metal core. All calculations were performed using the Gaussian 03 package. ${ }^{22}$ Geometry optimization of the two clusters was obtained with a two-level ONIOM procedure, ${ }^{23}$ in which the B3PW91/LANLD2Z ${ }^{24 \mathrm{a}}$ (D95 $\mathrm{V}^{24 \mathrm{~b}}$ for first row atoms) was used as higher level (QM) and the UFF molecular mechanics force field ${ }^{25}$ was employed as lower level (MM) of theory. No negative frequencies where found for the two optimized geometries. Energies and orbitals for 1, 3 and $\mathbf{5}$ were obtained by performing a single-point calculation at the B3PW91/LANLD2Z for heavy atoms and at the B3PW91/6-31G**26 for the light atoms. This approach yielded very good agreement with experimentally determined metal-metal bond lengths but the metal sulfur bond lengths were significantly elongated with respect to the observed values (Table 2 and 3). This elongation of metal ligand bond lengths is often observed when an $f$ polarization is not applied to the metals as is the case here. ${ }^{27}$ For the purposes of comparing the nature of the metal based orbitals this approach is adequate and saved considerable computational time. The HOMO orbital in $\mathbf{1}$ is highly localized in the $\mathrm{Ru}_{3} \mathrm{Sn}$ plane and shows a particularly dense bonding region between the stannylene $\operatorname{Sn}(3)$ and the central $\mathrm{Ru}$ atom, $\mathrm{Ru}(2)$ (Figure 4a). The HOMO orbital for $\mathbf{3}$ is also localized in the $\mathrm{Os}_{3} \mathrm{Sn}$ metal core but has electron density in more out of plane regions and involves the $\mathrm{Os}(2)-\mathrm{SPh}$ and $\mathrm{Os}(3)-\mathrm{SPh}$ moieties (Figure 5a). These differences are in agreement with the observed very short $\mathrm{Ru}(2)-\mathrm{Sn}(3)$ bond length relative to the other $\mathrm{Sn}-\mathrm{Ru}$ bonds in 1, while in 3 the related $\mathrm{Os}(2)-\mathrm{Sn}(1)$ bond is only slightly shorter than the other two Os-Sn interactions (Table 3). The LUMO orbital for $\mathbf{1}$ is metal based and shows a bonding region in the area of $\mathrm{Ru}(1)-\mathrm{Sn}(3)-\mathrm{Ru}(3)$ while the LUMO for 3 is mainly localized on Os(1) and Os (2) and is antibonding in nature (Figure 5b). This is in agreement with the larger HOMO-LUMO gap observed for $5\left(0.136 \mathrm{eV}, 1096 \mathrm{~cm}^{-1}\right)$ relative to $\mathbf{1}\left(\left(0.095 \mathrm{eV}, 766 \mathrm{~cm}^{-1}\right)\right.$. 


\section{Conclusions}

In summary, bimetallic compounds $\left[\mathrm{Ru}_{3}(\mathrm{CO})_{8}(\mu-\mathrm{SPh})_{2}\left(\mu_{3}-\mathrm{SnPh}_{2}\right)\left(\mathrm{SnPh}_{3}\right)\right] \mathbf{1},\left[\mathrm{Ru}_{3}(\mathrm{CO})_{8}(\mu-\right.$ $\left.\mathrm{SPh})_{2}\left(\mu_{3}-\mathrm{GePh}_{2}\right)\left(\mathrm{GePh}_{3}\right)\right] \quad \mathbf{2}, \quad\left[\mathrm{Os}_{3}(\mathrm{CO})_{9}(\mu-\mathrm{SPh})\left(\mu-\mathrm{SnPh}_{2}\right)(\mathrm{MeCN})\left(\eta^{1}-\mathrm{C}_{6} \mathrm{H}_{5}\right)\right] \quad \mathbf{3} \quad$ and $\left[\mathrm{Ru}_{3}(\mathrm{CO})_{6}(\mu-\mathrm{dppm})\left(\mu_{3}-\mathrm{S}\right)\left(\mu_{3}-\mathrm{SPh}\right)\left(\mathrm{SnPh}_{3}\right)\right] \mathbf{5}$ have been synthesized and structurally characterized. Compounds $\mathbf{1}$ and $\mathbf{2}$ further expand the chemistry involving the multiple additions of tin and germanium ligands to metal carbonyl cluster complexes. The new Ru-Sn, $\mathrm{Ru}-\mathrm{Ge}$ and Os-Sn bimetallic clusters reported in this study should be useful precursors for the preparation of new heterogeneous nano-scale catalysts on supports. Of particular interest is the very short Ru-Sn bond observed in 1. DFT calculations are consistent with this being a stannylene-Ru donor acceptor interaction. This bond would be expected to be particularly more reactive towards supports with Lewis acid character providing an initial binding site for eventual nano-catalyst formation.

\section{Experimental}

\section{General data}

Unless otherwise stated all the reactions were performed under a nitrogen atmosphere using standard Schlenk techniques. Solvents were dried and distilled prior to use by standard methods. $\left[\mathrm{Ru}_{3}(\mathrm{CO})_{12}\right]$ was purchased from Strem and $\left[\mathrm{Os}_{3}(\mathrm{CO})_{10}(\mathrm{MeCN})_{2}\right]^{28}$ and $\left[\mathrm{Ru}_{3}(\mathrm{CO})_{10}(\mu-\mathrm{dppm})\right]^{29}$ were prepared according to the literature methods. Infrared spectra were recorded on a Shimadzu FTIR 8101 spectrophotometer. ${ }^{1} \mathrm{H}$ and ${ }^{31} \mathrm{P}\left\{{ }^{1} \mathrm{H}\right\}$ and NMR spectra were recorded on Bruker DPX 400 instruments. ${ }^{119} \mathrm{Sn}$ NMR spectra were recorded on a Bruker ACS 300 spectrometer. All chemical shifts are reported in $\delta$ units with reference to the residual protons of the deuterated solvents for proton, to external $85 \% \mathrm{H}_{3} \mathrm{PO}_{4}$ for ${ }^{31} \mathrm{P}$ and $\mathrm{SnMe}_{4}$ for ${ }^{119} \mathrm{Sn}$ chemical shifts. Elemental analyses were performed by Schwarzkopf Microanalytical Laboratories, Woodside, NY. Mass spectra were recorded on a Fisons Platform II ESI mass spectrometer, with $\mathrm{MeOH}$ as mobile phase and $\mathrm{NaOMe}$ added as an ionization aid. ${ }^{16}$ The $\mathrm{m} / \mathrm{z}$ values reported are the strongest in the isotope envelope, and formulations were confirmed by matching isotope patterns with simulated ones generated with ISOTOPE. ${ }^{30}$ Fast atom bombardment mass spectra were obtained on a JEOL SX-102 spectrometer using 3-nitrobenzyl alcohol as matrix and CsI as calibrant. 
Reaction of $\left[\mathrm{Ru}_{3}(\mathbf{C O})_{12}\right]$ with $\mathbf{P h}_{3} \mathbf{S n S P h}$. To a benzene solution $\left(30 \mathrm{~cm}^{3}\right)$ of $\left[\mathrm{Ru}_{3}(\mathrm{CO})_{12}\right]$ (100 mg, $0.16 \mathrm{mmol}$ ) was added $\mathrm{Ph}_{3} \mathrm{SnSPh}(144 \mathrm{mg}, 0.32 \mathrm{mmol})$ and the reaction mixture was heated to reflux at $80{ }^{\circ} \mathrm{C}$ for $45 \mathrm{~min}$. The solvent was removed in vacuo and the residue chromatographed by TLC on silica gel. Elution with hexane/ $\mathrm{CH}_{2} \mathrm{Cl}_{2}(4: 1, \mathrm{v} / \mathrm{v})$ developed two bands. The faster moving band gave unconsumed starting material $(30 \mathrm{mg})$, while the slower moving band afforded $\left[\mathrm{Ru}_{3}(\mathrm{CO})_{8}(\mu-\mathrm{SPh})_{2}\left(\mu_{3}-\mathrm{SnPh}_{2}\right)\left(\mathrm{SnPh}_{3}\right)_{2}\right] \mathbf{1}(51 \mathrm{mg}, 18 \%)$ as blue-red crystals after recrystallization from hexane/ $\mathrm{CH}_{2} \mathrm{Cl}_{2}$ at $-4^{\circ} \mathrm{C}$. Anal. Calc. for $\mathrm{C}_{68} \mathrm{H}_{50} \mathrm{O}_{8} \mathrm{Ru}_{3} \mathrm{~S}_{2} \mathrm{Sn}_{3}$ : C, 47.52; H, 2.93. Found: C, 47.71, H, 3.11. IR (v $\left.v_{\mathrm{CO}}, \mathrm{CH}_{2} \mathrm{Cl}_{2}\right): 2090 \mathrm{w}$, $2052 \mathrm{~m}, 2043 \mathrm{~m}, 2023 \mathrm{vs}, 1998 \mathrm{~m} \mathrm{~cm}^{-1} .{ }^{1} \mathrm{H}$ NMR $\left(\mathrm{CDCl}_{3}\right): \delta 7.77-6.73(\mathrm{~m}, 50 \mathrm{H}) ; .{ }^{119} \mathrm{Sn}$ NMR $\left(\mathrm{CDCl}_{3}\right): \delta-25.3$ (s, 2Sn, $\mathrm{Ph}_{3} \mathrm{Sn}$ ); -29.9 (s, 1Sn, $\mathrm{Ph}_{2} \mathrm{Sn}$ ) ppm. FAB MS: m/z 1719 $[\mathrm{M}]^{+}$. ESI-MS: $m / z 1750[\mathrm{M}+\mathrm{OMe}]^{-}, 1719[\mathrm{M}]^{-}, 1369$ [M-SnPh $\left._{3}\right]^{-}$.

Reaction of $\left[\mathrm{Ru}_{3}(\mathrm{CO})_{12}\right]$ with $\mathrm{Ph}_{3} \mathbf{G e S P h}$. A similar reaction to that above between $\left[\mathrm{Ru}_{3}(\mathrm{CO})_{12}\right](100 \mathrm{mg}, 0.16 \mathrm{mmol})$ with $\mathrm{Ph}_{3} \mathrm{GeSPh}(129 \mathrm{mg}, 0.31 \mathrm{mmol})$ in benzene $\left(30 \mathrm{~cm}^{3}\right)$ followed by similar chromatographic separation developed two bands. The faster moving band gave unconsumed starting material (37 mg, 37\%), while the slower moving band afforded $\left[\mathrm{Ru}_{3}(\mathrm{CO})_{8}(\mu-\mathrm{SPh})_{2}\left(\mu-\mathrm{GePh}_{2}\right)\left(\mathrm{GePh}_{3}\right)_{2}\right] 2(36 \mathrm{mg}, 15 \%)$ as deep red crystals after recrystallization from hexane/ $\mathrm{CH}_{2} \mathrm{Cl}_{2}$ at $-4^{\circ} \mathrm{C}$. Anal. Calc. for $\mathrm{C}_{68} \mathrm{H}_{50} \mathrm{O}_{8} \mathrm{Ru}_{3} \mathrm{~S}_{2} \mathrm{Ge}_{3}$ : C, 51.68; $\mathrm{H}, 3.19$. Found: C, 51.71, H, 3.13. :IR ( $\left.v_{\mathrm{CO}}, \mathrm{CH}_{2} \mathrm{Cl}_{2}\right)$ : 2092 w, $2056 \mathrm{~m}, 2045 \mathrm{~m}, 2021$ vs, $1996 \mathrm{~m} \mathrm{~cm}^{-1} .{ }^{1} \mathrm{H} \mathrm{NMR}\left(\mathrm{CDCl}_{3}\right): \delta 8.32-6.48(\mathrm{~m} \mathrm{50H})$.

Reaction of $\left[\mathrm{Os}_{3}(\mathrm{CO})_{10}(\mathrm{MeCN})_{2}\right]$ with $\mathbf{P h}_{3} \mathrm{SnSPh}$. A benzene solution $(75 \mathrm{~mL}$ ) of $\left[\mathrm{Os}_{3}(\mathrm{CO})_{10}(\mathrm{MeCN})_{2}\right](180 \mathrm{mg}, 0.19 \mathrm{mmol})$ and $\mathrm{Ph}_{3} \mathrm{SnSPh}(87 \mathrm{mg}, 0.19 \mathrm{mmol})$ was refluxed for $7 \mathrm{~h}$. Workup as described above afforded $\left[\mathrm{Os}_{3}(\mathrm{CO})_{9}(\mu-\mathrm{SPh})\left(\mu-\mathrm{SnPh}_{2}\right)(\mathrm{MeCN})\left(\eta^{1}-\mathrm{C}_{6} \mathrm{H}_{5}\right)\right]$ 3 (69 mg, 27\%) as yellow crystals from hexane/ $\mathrm{CH}_{2} \mathrm{Cl}_{2}$ at $-4^{\circ} \mathrm{C}$. Anal. Calc. for $\mathrm{C}_{35} \mathrm{H}_{23} \mathrm{~N}_{1} \mathrm{O}_{9} \mathrm{Os}_{3} \mathrm{~S}_{1} \mathrm{Sn}_{1}$ : C, 31.77; H, 1.75. Found: C, 31.82; H, 1.72\%. IR ( $\left.v_{\mathrm{CO}}, \mathrm{CH}_{2} \mathrm{Cl}_{2}\right) 2098$ m, $2058 \mathrm{w}, 2024 \mathrm{vs}, 2013 \mathrm{~s}, 1986 \mathrm{~m}, 1965 \mathrm{w} \mathrm{cm}^{-1} .{ }^{1} \mathrm{H}$ NMR $\left(\mathrm{CDCl}_{3}\right): \delta$ 8.07-6.99 (m, 20H), 1.69 (s, 3H). FAB MS: m/z 1323 [M] $]^{+}$. ESI-MS: m/z 1354 [M+OMe] $]^{-} 1313$ [M+OMe$\mathrm{MeCN}]^{-}$. 
Reaction of $\left[\mathbf{R u}_{\mathbf{3}}(\mathbf{C O})_{\mathbf{1 0}}\left(\boldsymbol{\mu}\right.\right.$-dppm)] with $\mathbf{P h}_{\mathbf{3}} \mathbf{S n S P h} . \mathrm{Ph}_{3} \mathrm{SnSPh}(142 \mathrm{mg}, 0.31 \mathrm{mmol})$ was added to a benzene solution $\left(50 \mathrm{~cm}^{3}\right)$ of $\left[\mathrm{Ru}_{3}(\mathrm{CO})_{10}(\mu-\mathrm{dppm})\right] 4(100 \mathrm{mg}, 0.10 \mathrm{mmol})$. The reaction mixture was heated to reflux for 30 min during which time the color changed from orange to deep red. A similar chromatographic separation to that above yielded $\left[\mathrm{Ru}_{3}(\mathrm{CO})_{6}(\mu-\right.$ dppm $\left.)\left(\mu_{3}-\mathrm{S}\right)\left(\mu_{3}-\mathrm{SPh}\right)\left(\mathrm{SnPh}_{3}\right)\right] 5(75 \mathrm{mg}, 54 \%)$ as yellow crystals from hexane $/ \mathrm{CH}_{2} \mathrm{Cl}_{2}$ at $4^{\circ} \mathrm{C}$. Anal. Calc. for $\mathrm{C}_{55} \mathrm{H}_{42} \mathrm{O}_{6} \mathrm{P}_{2} \mathrm{Ru}_{3} \mathrm{~S}_{2} \mathrm{Sn}_{1}$ : C, 49.04; H, 3.14. Found: C, 49.10; H, 3.17\%. IR

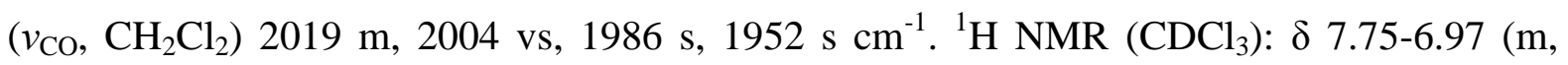
$40 \mathrm{H}), 4.18(\mathrm{~m}, 1 \mathrm{H}), 3.70(\mathrm{~m}, 1 \mathrm{H}) .{ }^{31} \mathrm{P}\left\{{ }^{1} \mathrm{H}\right\} \mathrm{NMR}\left(\mathrm{CDCl}_{3}\right): \delta 32.6(\mathrm{~d}, J=88.1 \mathrm{~Hz}),-13.2(\mathrm{~d}$, $J=88.1 \mathrm{~Hz}) \cdot{ }^{119} \mathrm{Sn} \mathrm{NMR}\left(\mathrm{CDCl}_{3}\right): \delta-28.6\left[\mathrm{~d},{ }^{3} J\left({ }^{31} \mathrm{P}-{ }^{119} \mathrm{Sn}\right)=15 \mathrm{~Hz}\right]$. FAB MS: $m / z 1348$ $[\mathrm{M}]^{+}$, ESI-MS: m/z (negative ion mode) 1379 [M+OMe] $]^{-} 1347[\mathrm{M}-\mathrm{H}]^{-}$; (positive ion mode) $1371[\mathrm{M}+\mathrm{Na}]^{+}$.

\section{X-ray Crystallography.}

X-ray intensity data were collected on a Bruker SMART CCD diffractometer with Mo-K $\alpha$ Xrays using standard procedures and software. Semi-empirical absorption corrections were applied (SADABS). ${ }^{31}$ Structures were solved by direct methods and developed and refined on $\mathrm{F}^{2}$ using the SHELX programmes ${ }^{32}$ operating under WinGX. ${ }^{33}$ Hydrogen atoms were included in calculated positions.

\section{Electrochemistry}

Electrochemical measurements were performed using a BAS CV-50W analyzer equipped with a standard three-electrode cell. The cell was designed to allow the tip of the reference electrode to approach closely to the working electrode. Voltammetric experiments were performed using aqueous $\mathrm{Ag} / \mathrm{AgCl}$ as a reference electrode, a glassy carbon as a working electrode and platinum wire as the auxiliary electrode. Potential data are referenced to the ferreocene(0/+) couple, which is oxidized in $\mathrm{CH}_{2} \mathrm{Cl}_{2}$ at $+0.48 \mathrm{~V}$ vs $\mathrm{Ag} / \mathrm{AgCl}$. Typically, a solution containing $1 \mathrm{mM}$ of the cluster and $0.1 \mathrm{M}$ supporting electrolyte (tetrabutylammonium hexafluorophosphate, $\mathrm{Bu}_{4} \mathrm{NPF}_{6}$ ) was prepared using freshly distilled dichloromethane. The solution was degassed prior to introducing the sample and also between runs. Positive feedback $i \mathrm{R}$ compensation was routinely applied. 


\section{Computational Details}

All calculations were performed using the Gaussian 03 package. ${ }^{22}$ Geometry optimization of the two clusters was obtained with a two-level ONIOM procedure, ${ }^{23}$ in which the B3PW91/LANLD2Z ${ }^{24 a}$ (D95V ${ }^{24 b}$ for first row atoms) was used as higher level (QM) and the UFF molecular mechanics force field ${ }^{25}$ was employed as lower level (MM) of theory. No negative frequencies where found for the two optimized geometries. Energies and orbitals for 1, 3 and 5 were obtained by performing a single-point calculation at the B3PW91/LANLD2Z for heavy atoms and at the B3PW91/6-31G**26 for the light atoms.

\section{Supplementary information}

Crystallographic data for the structural analyses have been deposited with the Cambridge Crystallographic Data Center, CCDC Nos. 661316-661318 for compounds 1, 3 and 5. Copies of this information may be obtained free of charge from the Director, CCDC, 12 Union Road, Cambridge, CB2 1 EZ, UK (fax: +44-1223-336033; e-mail: deposit@ccdc.cam.ac.uk or www: http://www.ccdc.ac.uk).

\section{Acknowledgements}

We thank Dr. Tania Groutso, University of Auckland for collection of X-ray intensity data, and Kelly Kilpin, University of Waikato, for obtaining ${ }^{119} \mathrm{Sn}$ NMR data. One of us (AKR) gratefully acknowledges the University Grants Commission of Bangladesh for a Scholarship. Support for this research by the Department of Energy (E.R., grant \# DE-FG02-01ER45869) is also gratefully acknowledged.

\section{References}

1 (a) J. M. Thomas, R. Raja and D. W. Lewis, Angew. Chem., Int. Ed., 2005, 44, 6456; (b) J. M. Thomas, B. F. G. Johnson, R. Raja, G. Sankar and P. A. Midgley, Acc. Chem. Res., 2003, 36, 20; (c) J. M. Thomas, R. Raja, B. F. G. Johnson, S. Hermans, M. D. Jones and T. Khimyak, Ind. Eng. Chem. Res., 2003, 42, 1563; (d) B. F. G. Johnson, Top. Catal., 2003, 24, 147.

2 (a) S. M. Santos, A. M. Silva, E. Jordao and M. A. Fraga, Catal. Commun. 2004, 5, 377; (b) S. Hermans, R. Raja, J. M. Thomas, B. F. G. Johnson, G. Sankar and D. 
Gleson, Angew. Chem., Int. Ed., 2001, 40, 1211; (c) S. Hermans and B. F. G. Johnson, J. Chem. Soc., Chem. Commun., 2000, 1955.

3 (a) R. Burch, J. Catal., 1981, 71, 348; (b) R. Burch and L. C. Garla, J. Catal., 1981, 71, 360; (b) R. Srinivasan and B. H. Davis, Platinum Met. Rev., 1992, 36, 151; (c) T. Fujikawa, F. H. Ribeiro and G. A. Somorjai, J. Catal. 1998, 178, 58.

(a) G. W. Huber, J. W. Shabaker and J. A. Dumesic, Science, 2003, 300, 2075; (b) M.

S. Holt, W. L. Wilson and J. H. Nelson, Chem. Rev., 1989, 89, 11.

5 B. F. G. Johnson, S. A. Raynor, D. B. Brown, D. S. Shephard, T. Mashmeyer, J. M. Thomas, S. Hermans, R. Raja and G. Sankar, J. Mol. Catal. A: Chem., 2002, 182-183, 89.

6. (a) G. Lafaye, C. Micheaud-Especel, C. Montassier, P. Marecot, Appl. Catal. A, 2002, 230, 19; (b) B. Didillon, J. P. Candy, F. Lepepetier, O. A. Ferretti and J. M. Basset, Stud. Surf. Sci. Catal., 1993, 78, 147; (c) (a) G. Lafaye, C. Mihut, C. Especel, M. D. Amiridis. Langmuir, 2004, 20, 10612.

7 A. Hungria, R. Raja, R. D. Adams, B. Captain, J. M. Thomas, P. A. Midgley, V. Golvenko and B. F. G. Johnson, Angew. Chem., Int. Ed., 2006, 45, 969.

8 (a) K. Burgess, C. Guerin, B. F. G. Johnson and J. Lewis, J. Organomet. Chem., 1985, 295, C3; (b) W. K. Leong, R. K. Pomeroy, R. J. Batchelor, F. W. B. Einstein and C. F. Campana, Organometallics, 1996, 15, 1582.

9 (a) R. J. Hall, P. Serguievski and J. B. Keister, Organometallics, 2000, 19, 4499; (b) F. W. B. Einstein, R. K. Pomeroy and A. C. Willis, J. Organomet. Chem., 1986, 311, 257.

10 (a) R. D. Adams, B. Captian, W. Fu and M. D. Smith, Inorg. Chem., 2002, 41, 5593; (b) R. D. Adams, B. Captian, W. Fu and M. D. Smith, Inorg. Chem., 2002, 41, 2302; (c) R. D. Adams, B. Captain, J. L. Smith, M. B. Hall, C. L. Beddie, C. E. Wedster, W. Fu and M. D. Smith, Inorg. Chem., 2004, 43, 7576; (d) R. D. Adams, B. Captain, and L. Zhu, Organometallics, 2006, 25, 2049; (e) R. D. Adams, B. Captain and L. Zhu, Organometallics, 2006, 25, 4183; (f) R. D. Adams, B. Captain and L. Zhu, Inorg. Chem., 2007, 46, 4605.

11 M. R. Hassan, G. Hogarth, G. M. G. Hossain, S. E Kabir, A. K. Raha, M. S. Saha and D. A. Tocher, Organometallics, 2007, 26, 6473. 
12 Cambridge Crystallographic Database, V5.28 + updates, 2007; F. H. Allen, Acta Cryst., 2002, B58, 380.

13 J. D. Cotton, P. J. Davidson, D. E. Goldberg, M. F. Lappert and K. M. Thomas, J. Chem. Soc., Chem. Commun., 1974, 893.

14 (a) R. F. Gerlach, K. M. Mackay and B. K. Nicholson, Rev. Silicon, Germanium, Tin and Lead Compounds, 1981, 5, 67; (b) K. M. Mackay and B. K. Nicholson, in Ch 43, G. Wilkinson, F. G. A. Stone and E. W. Abel (Eds), Comprehensive Organometallic Chemistry, Pergamon, Oxford, 1982; (c) W. K. Leong, F. W. B. Einstein and R. K. Pomeroy, Organometallics, 1996, 1582; (d) C. J. Cardin, D. J. Cardin, M. A. Convery, Z. Dauter, D. Fenske, M. M. Devereux and M. B. Power, J. Chem. Soc., Dalton Trans., 1996, 1133; (e) R. D. Adams, B. Captain , W. Fu and M. B. Smith, J. Organomet. Chem., 2003, 671, 158.

15 (a) R. D. Adams, B. Captain, R. H. Herber, K. Johansson, I. Nowik, J. L. Smith and M. D. Smith, Inorg. Chem., 2005, 44, 6346; (b) R. D. Adams, B. Captain, K. Johansson and J. L. Smith, J. Am. Chem. Soc., 2005, 127, 488.

16 W. Henderson, J. S. McIndoe, B. K. Nicholson and P. J. Dyson, J. Chem. Soc., Dalton Trans., 1998, 519.

17 (a) J. A. K. Howard and P. Woodward, J. Chem. Soc., A, 1971, 3648; (b) Y. Zhang, B. Wang, S. Xu and X. Zhou Organometallics, 2001, 20, 3829; (c) R. D. Adams, B. Captain and W. Fu, Inorg. Chem., 2003, 42, 1328; (d) R. D. Adams, B. Captain and W. Fu, J. Organomet. Chem. 2003, 671, 158; (e) R. D. Adams, B. Captain and W. Fu, Inorg. Chem., 2005, 44, 6623.

18 R. D. Adams, E. M. Boswell, B. Captian and M. A. Patel, Inorg. Chem., 2007, 46, 533; see also R. D. Adams, B. Captain, and E. Trufan, J. Cluster Sci., 2007, 18, 642.

19 N. Viswanathan, E. D. Morrison, G. L. Geoffroy, S. J. Geib, and A. L. Rheingold, Inorg. Chem., 1986, 25, 3100.

20. A. W. Coleman, D. F. Jones, P. H. Dixneuf, C. Brisson, J. -J. Bonnet and G. Lavigne, Inorg. Chem., 1984, 23, 952.

21 e.g. see A. B. Antonova, M. I. Bruce, P. A. Humphrey, M. Gaudio, B. K. Nicholson, N. Scoleri, B. W. Skelton, A. H. White and N. N. Zaitseva, J. Organomet. Chem., 2006, 691, 4694. 
22 (a) F. Maseras and K. Morokuma, J. Comput. Chem., 1995, 16, 1170. (b) S. Humbel, S. Sieber and K. Morokuma, J. Chem. Phys. 1996, 105, 1959-1967.

23 A. K. Rappé, C. J. Casewit, K. S. Colwell, W. A. Goddard and W. M. Skiff, J. Am. Chem. Soc. 1992, 114, 10024.

24 (a) P. J. Hay and W. R. Wadt, J. Chem. Phys., 1985, 82, 270. (b) T. H. Dunning Jr. and P. J. Hay, in Modern Theoretical Chemistry, Ed. H. F. Schaefer III, Vol. 3 (Plenum, New York, 1976, 1-28.

25 R. Ditchfield, W. J. Hehre, and J. A. Pople, J. Chem. Phys., 1971, 54, 724.

26 M. J. Frisch, G. W. Trucks, H. B. Schlegel, G. E. Scuseria, M. A. Robb, J. R. Cheeseman, J. A. Montgomery Jr., T. Vreven, K. N. Kudin, J. C. Burant, J. M. Millam,S. S. Iyengar, J. Tomasi, V. Barone, B. Mennucci, M. Cossi, G. Scalmani, N. Rega, G. A. Petersson, H. Nakatsuji, M. Hada, M. Ehara, K. Toyota, R. Fukuda, J. Hasegawa, M. Ishida, T. Nakajima, Y. Honda, O. Kitao, H. Nakai, M. Klene, X. Li, J. E. Knox, H. P. Hratchian, H. P., Cross, J. B., Adamo, C., Jaramillo, J., Gomperts, R., Stratmann, R. E., Yazyev, O., Austin, A. J., Cammi, R., Pomelli, C., Ochterski, J., Ayala, P. Y., Morokuma, K., Voth, G. A., Salvador, P., Dannenberg, J. J., Zakrzewski, V. G., Dapprich, S., Daniels, A. D., Strain, M. C., Farkas, O., Malick, D. K., Rabuck, A. D., Raghavachari, K., Forestman, J. B, Ortiz, J. V., Cui, Q., Baboul, A. G., Clifford, S., Cioslowski, J., Stefanov, B. B, Liu, G., Liashenko, A., Piskorz, P., Komaromi, I., Martin, R. L., Fox, D. J., Keith, T., Al-Laham, M. A., Peng, C. Y., Nanayakkara, A., Challacombe, M., Gill, P. M. W., Johnson, B., Chen, W, Wong, M. W., Gonzales, C., and Pople, J. A. Gaussian 03. (revision C.02). 2004. Wallingford CT, Gaussian Inc.

27. D. G. Musaev, T. Nowroozi-Isfahani, K. Morokuma, E. Roseneberg, Organometallics, 2005, 24, 5973.

28. J. Lewis, P. J. Dyson, B. J. Alexander, B. F. G. Johnson, C. M. Martin, J. M. G. Nairn and E. Parsini, J. Chem. Soc., Dalton Trans., 1993, 519.

29 M. I. Bruce, J. G. Matisons and B. K. Nicholson, J. Organomet. Chem., 1983, 247, 321.

30 L. J. Arnold, J. Chem. Educ., 1992, 69, 811.

31 R. H. Blessing, Acta Cryst., 1995, A51, 33.

32 G. M. Sheldrick, SHELX97 Programs for the solution and refinement of crystal structures, University of Göttingen, Germany, 1997. 
33 (a) L. J. Farrugia, WinGX, Version 1.70.01, University of Glasgow, UK; (b) L. J. Farrugia, J. Appl. Cryst., 32, 1999, 837.

\section{Table 1}

Crystallographic data and structure refinement ${ }^{\mathrm{a}}$ for $\mathbf{1 , 3}$ and 5

\begin{tabular}{|c|c|c|c|}
\hline & 1 & 3 & 5. $\mathrm{CH}_{2} \mathrm{Cl}_{2}$ \\
\hline Empirical formula & $\mathrm{C}_{68} \mathrm{H}_{50} \mathrm{O}_{8} \mathrm{Ru}_{3} \mathrm{~S}_{2} \mathrm{Sn}_{3}$ & $\mathrm{C}_{35} \mathrm{H}_{23} \mathrm{NO}_{9} \mathrm{Os}_{3} \mathrm{SSn}$ & $\mathrm{C}_{55} \mathrm{H}_{42} \mathrm{O}_{6} \mathrm{P}_{2} \mathrm{Ru}_{3} \mathrm{~S}_{2} \mathrm{Sn}$ \\
\hline Formula weight & 1718.48 & 1322.89 & 1431.77 \\
\hline Crystal system & Triclinic & Monoclinic & Triclinic \\
\hline Space group & $P \overline{1}$ & $P 2_{1} / \mathrm{n}$ & $P \overline{1}$ \\
\hline$a, \AA$ & $13.826(1)$ & $10.9339(2)$ & $11.9706(3)$ \\
\hline$b, \AA$ & $13.944(1)$ & $22.8143(2)$ & $12.1970(3)$ \\
\hline$c, \AA$ & $17.434(1)$ & $14.4812(2)$ & $19.8844(5)$ \\
\hline$\alpha, \operatorname{deg}$ & 73.71(1) & 90 & $101.979(1)$ \\
\hline$\beta, \operatorname{deg}$ & $79.20(1)$ & $95.212(1)$ & $103.825(1)$ \\
\hline$\gamma, \operatorname{deg}$ & $82.45(1)$ & 90 & $92.297(1)$ \\
\hline Volume, $\AA^{3}$ & $3157.9(4)$ & $3597.4(1)$ & 2745.1(1) \\
\hline$Z$ & 2 & 4 & 2 \\
\hline $\mathrm{D}_{\text {calc }}, \mathrm{Mg} / \mathrm{m}^{3}$ & 1.807 & 2.443 & 1.732 \\
\hline$\mu(\mathrm{Mo} \mathrm{K} \alpha), \mathrm{mm}^{-1}$ & 1.988 & 11.36 & 1.540 \\
\hline$F(000)$ & 1672 & 2424 & 1412 \\
\hline Crystal size, $\mathrm{mm}^{3}$ & $0.28 \times 0.26 \times 0.20$ & $0.28 \times 0.24 \times 0.20$ & $0.28 \times 0.18 \times 0.16$ \\
\hline$\theta_{\max } /^{\circ}$ & 26.4 & 26.3 & 26.3 \\
\hline \multirow[t]{3}{*}{ Index ranges } & $-27 \leq h \leq 27$ & $-18 \leq h \leq 18$ & $-50 \leq h \leq 45$ \\
\hline & $0 \leq k \leq 38$ & $-21 \leq k \leq 25$ & $0 \leq k \leq 13$ \\
\hline & $0 \leq l \leq 16$ & $0 \leq l \leq 27$ & $0 \leq l \leq 56$ \\
\hline Reflections collected & 29546 & 21313 & 26441 \\
\hline Independent reflections & $12812[R(\mathrm{int})=0.031]$ & $7303[R$ (int $)=0.024]$ & $11038[R(\mathrm{int})=0.020]$ \\
\hline Max. and min. transmn & 0.593 and 0.501 & 0.172 and 0.107 & 0.829 and 0.745 \\
\hline Parameters & 757 & 452 & 649 \\
\hline Goodness-of-fit on $F^{2}$ & 1.155 & 1.110 & 1.015 \\
\hline $\begin{array}{l}R \text { indices }[I>2 \sigma(I)] \\
w R \text { indices [all data] }\end{array}$ & $\begin{array}{l}R_{1}=0.0452 \\
\mathrm{w} R_{2}=0.0971\end{array}$ & $\begin{array}{l}R_{1}=0.0204 \\
\mathrm{w} R_{2}=0.0454\end{array}$ & $\begin{array}{l}R_{1}=0.0224 \\
\mathrm{w} R_{2}=0.0536\end{array}$ \\
\hline
\end{tabular}


Table 2.

Selected calculated and observed bond lengths and angles for compound $\mathbf{1}$

Bond lengths $(\AA)$

$$
\begin{aligned}
& \mathrm{Ru}(1)-\mathrm{Ru}(2) \\
& \mathrm{Ru}(2)-\mathrm{Ru}(3) \\
& \mathrm{Sn}(1)-\mathrm{Ru}(1) \\
& \mathrm{Sn}(3)-\mathrm{Ru}(1) \\
& \mathrm{Sn}(3)-\mathrm{Ru}(2) \\
& \mathrm{Sn}(3)-\mathrm{Ru}(3) \\
& \mathrm{Sn}(2)-\mathrm{Ru}(3) \\
& \mathrm{S}(1)-\mathrm{Ru}(1) \\
& \mathrm{S}(1)-\mathrm{Ru}(2) \\
& \mathrm{S}(2)-(\mathrm{Ru}(2) \\
& \mathrm{S}(2)-\mathrm{Ru}(3)
\end{aligned}
$$

Bond Angle (Degrees)

$\mathrm{Ru}(1)-\mathrm{Ru}(2)-\mathrm{Ru}(3)$ Calculated

$$
2.9462
$$$$
2.9466
$$

2.7446

3.0835

2.5544

3.1032

2.7473

2.524

2.523

2.5561

2.5539
Observed

2.9020(7)

2.9090(7)

2.6832(6)

3.0986(6)

2.5380(7)

3.0488(7)

2.6808(7)

2.423(2)

2.348(2)

2.345(2)

2.425(2)

136.00

$136.75(2)$ 


\section{Table 3.}

Selected calculated and observed bond lengths and angles for compound $\mathbf{3}$

Bond lengths $(\AA)$

$\begin{array}{ccc} & \text { Calculated } & \text { Observed } \\ \text { Os(1)-Os(2) } & 3.0557 & 3.0391(2) \\ \text { Os(2)-Os(3) } & 2.9900 & 2.9990(2) \\ \text { Os(1)-Sn((1) } & 3.1203 & 2.9981(3) \\ \text { Os(2)-Sn(1) } & 2.8003 & 2.7862(3) \\ \text { Os(3)-Sn(1) } & 2.8317 & 2.7476(3) \\ \text { Os(2)-S(1) } & 2.565 & 2.386(1) \\ \text { Os(1)-S(1) } & 2.546 & 2.405(1) \\ \text { Os(1)-C(11) } & 2.123 & 2.135(4)\end{array}$

Bond Angle (Degrees)

Os(1)-Os(2)-Os(3)

121.568

$117.836(7)$ 


\section{Captions to Figures.}

Figure 1.

The structure of the cluster $\left[\mathrm{Ru}_{3}(\mathrm{CO})_{8}(\mu-\mathrm{SPh})_{2}\left(\mu_{3}-\mathrm{SnPh}_{2}\right)\left(\mathrm{SnPh}_{3}\right)\right] \mathbf{1}$, shown with $30 \%$ ellipsoids. Selected parameters: $\mathrm{Ru}(1)-\mathrm{Ru}(2)$ 2.9020(7), $\mathrm{Ru}(2)-\mathrm{Ru}(3)$ 2.9090(7), $\mathrm{Sn}(3)-\mathrm{Ru}(1)$ 3.0986(7), $\operatorname{Sn}(3)-R u(3)$ 3.0488(7), Sn(3)-Ru(2) 2.5380(7), Sn(1)-Ru(1) 2.6832(6), Sn(2)$\mathrm{Ru}(3)$ 2.6808(7), S(1)-Ru(1) 2.423(2), S(1)-Ru(2) 2.348(2), S(2)-Ru(2) 2.345(2), S(2)-Ru(3) 2.425(2) $\mathrm{A} ; \mathrm{Ru}(1)-\mathrm{Ru}(2)-\mathrm{Ru}(3) 136.75(2)^{\circ}$.

\section{Figure 2.}

The structure of the cluster $\left[\mathrm{Os}_{3}(\mathrm{CO})_{9}(\mu-\mathrm{SPh})\left(\mu-\mathrm{SnPh}_{2}\right)(\mathrm{MeCN})\left(\eta^{1}-\mathrm{C}_{6} \mathrm{H}_{5}\right)\right]$ 3, shown with 30\% ellipsoids. Selected parameters: Os(1)-Os(2) 3.0391(2), Os(2)-Os(3) 2.9990(2), Sn(1)Os(1) 2.9981(3), Sn(1)-Os(2) 2.7862(3), Sn(1)-Os(3) 2.7476(3), Os(1)-S(1) 2.405(1), Os(2)$\mathrm{S}(1) 2.386(1), \mathrm{Os}(1)-\mathrm{C}(11) 2.135(4) \AA$; Os(1)-Os(2)-Os(3) $117.836(7)^{\circ}$.

\section{Figure 3.}

The structure of the cluster $\left[\mathrm{Ru}_{3}(\mathrm{CO})_{6}(\mu-\mathrm{dppm})\left(\mu_{3}-\mathrm{S}\right)\left(\mu_{3}-\mathrm{SPh}\right)\left(\mathrm{SnPh}_{3}\right)\right] \mathbf{5}$, shown with $30 \%$ ellipsoids. Selected parameters: $R u(1)-R u(2)$ 2.9030(3), $R u(2)-R u(3)$ 2.7481(3), $S n(1)-R u(1)$ 2.6139(3), S(1)-Ru(1) 2.3562(6), S(1)-Ru(2) 2.4130(6), S(1)-Ru(3) 2.3371(6), S(2)-Ru(1) 2.4476(6), S(2)-Ru(2) 2.4432(6), S(2)-Ru(3) 2.4746(6), P(1)-Ru(2) 2.3217(6), P(2)-Ru(3) 2.3202(6) $\AA$; $\mathrm{Ru}(1)-\mathrm{Ru}(2)-\mathrm{Ru}(3) \quad 85.63(1)^{\circ}$.

Figure 4.

HOMO (a) and LUMO (b) orbitals for compound 1.

Figure 5

HOMO (a) and LUMO (b) orbitals for compound 3. 


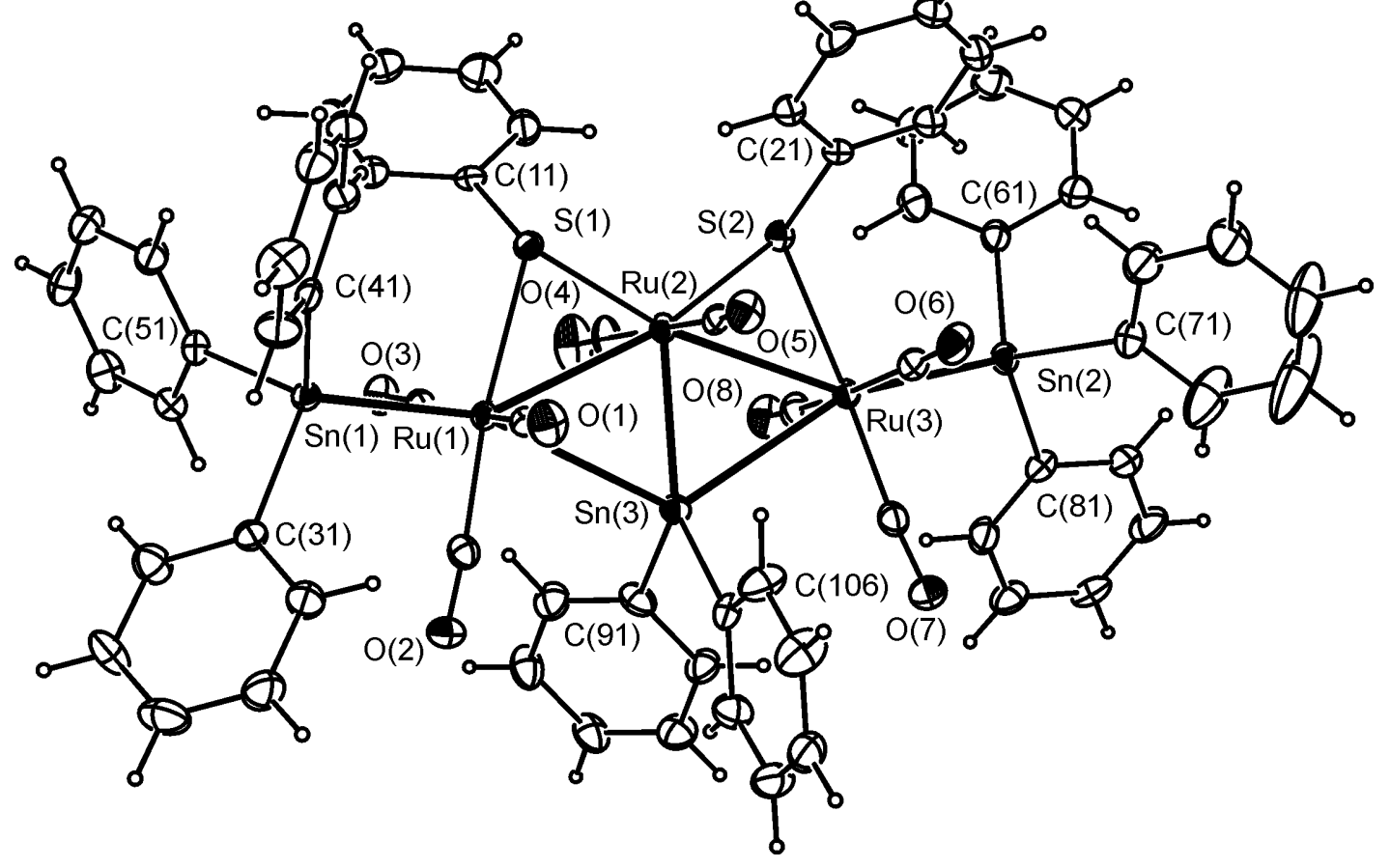

Figure 1

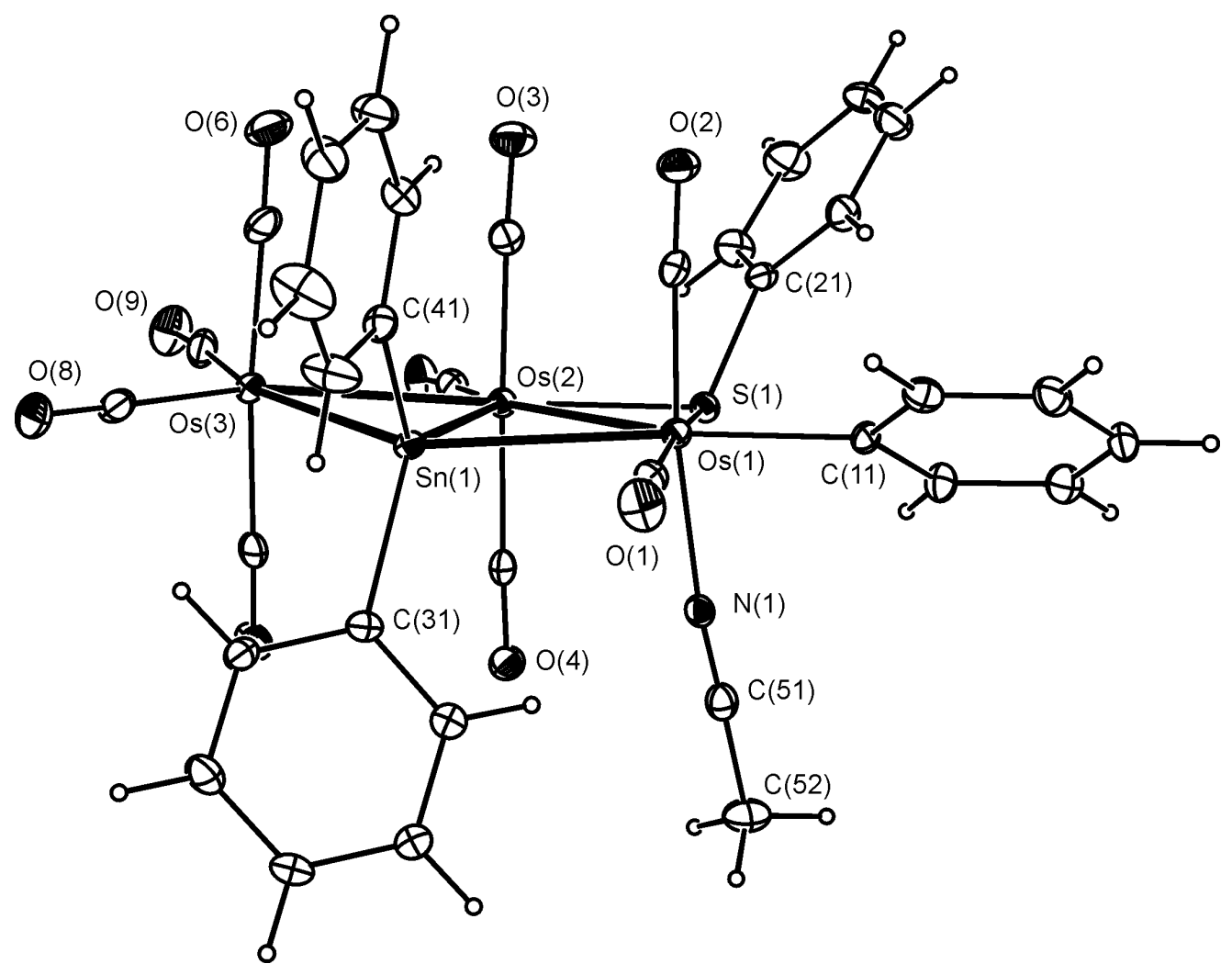

Figure 2 


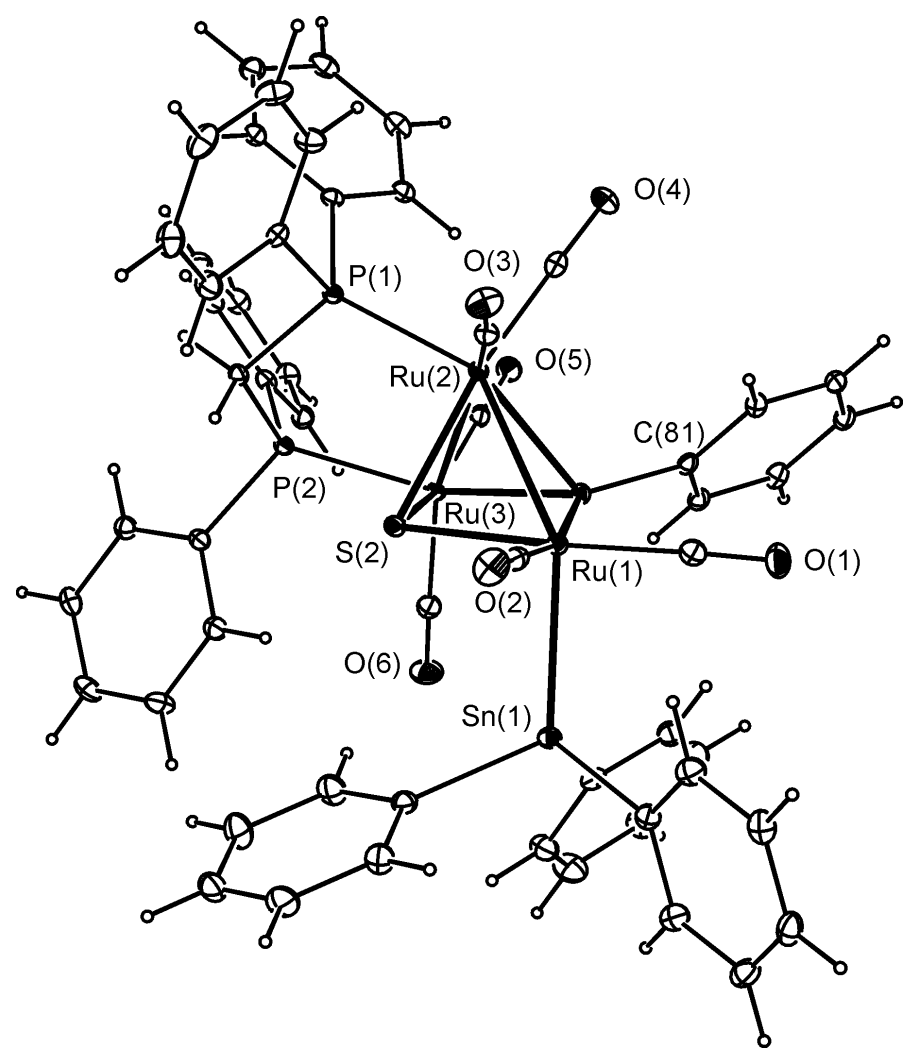

Figure 3 
Figure 4

a

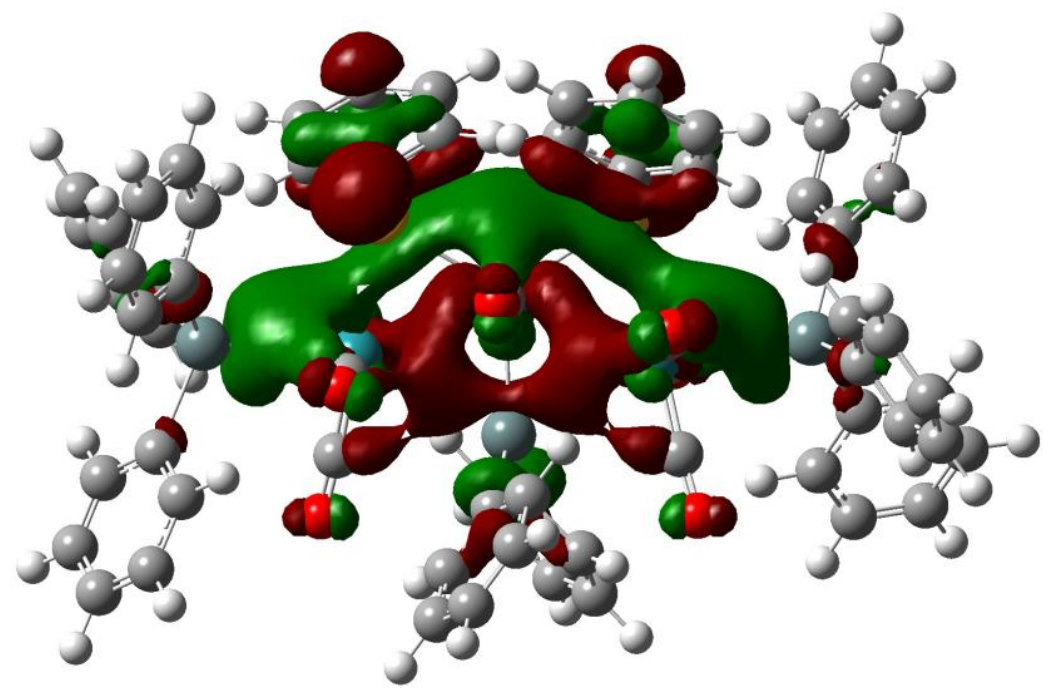

b

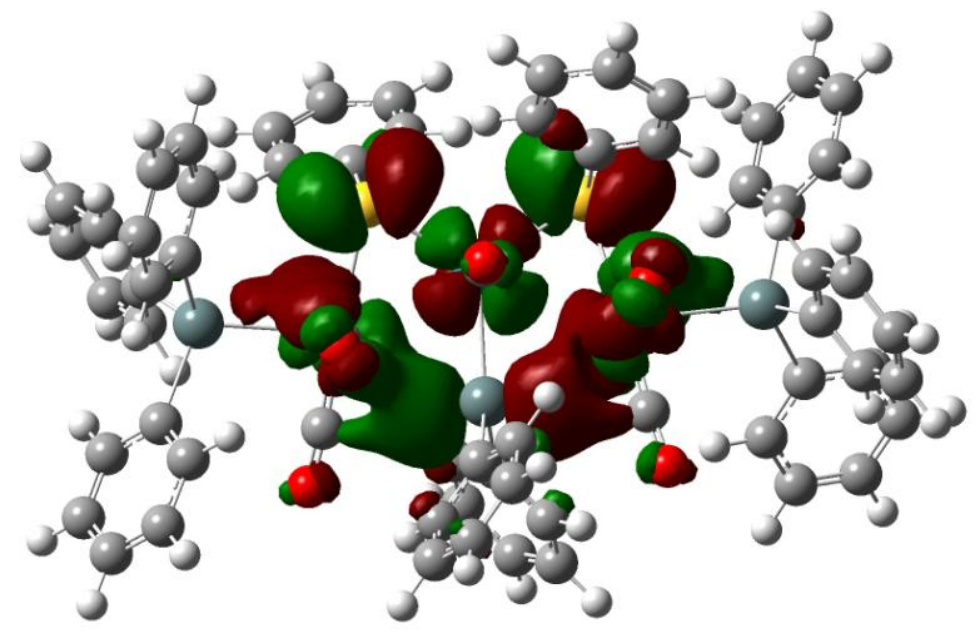


Figure 5

a

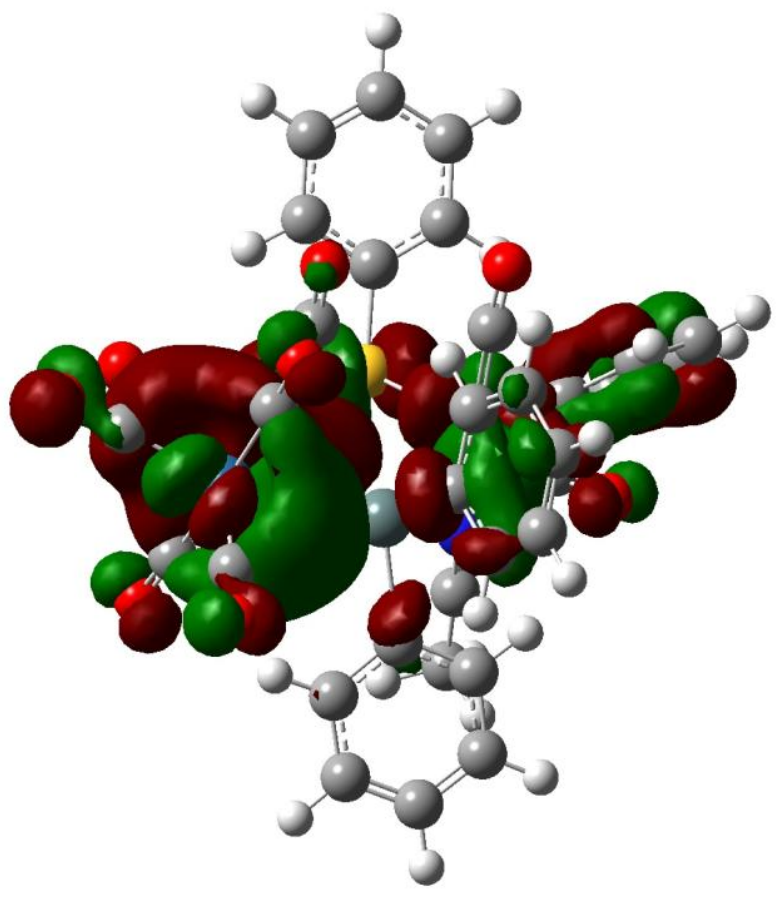

b

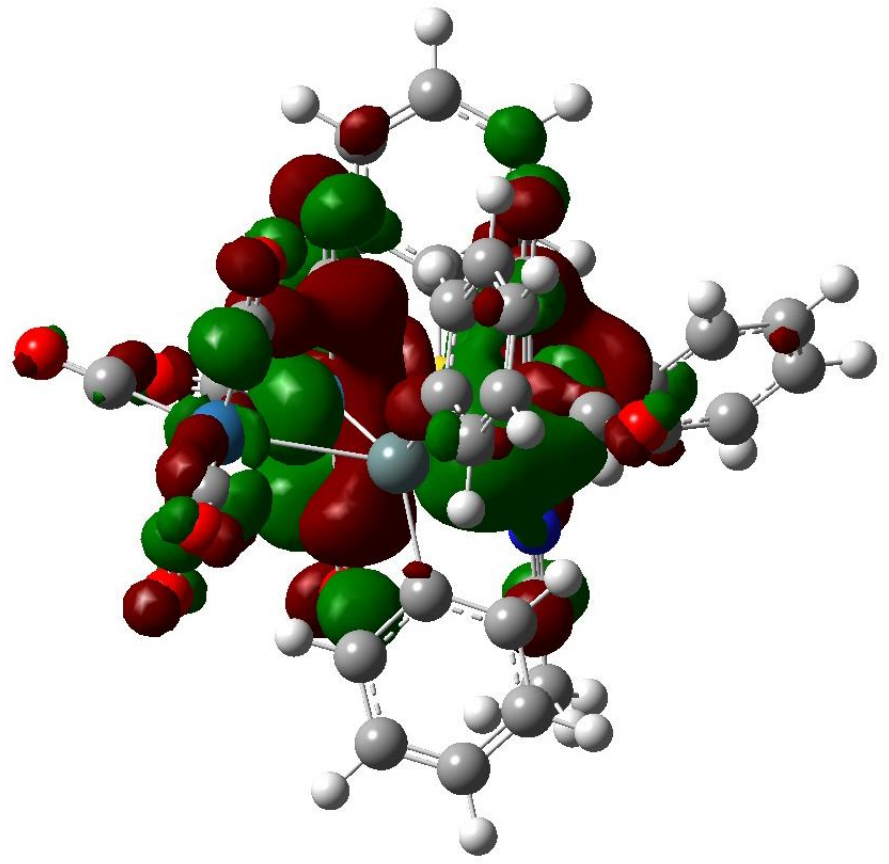

